\title{
PHYSICAL VOLCANOLOGY OF PYROCLASTIC TEPHRA DEPOSIT AT BATOKE MT. CAMEROON, WEST AFRICA: AN OVER VIEW.
}

\section{CAROLINE N. NGWA, LINUS NCHE AND CHEO E. SUH}

(Received 16 April 2013; Revision Accepted 23 May 2013)

\begin{abstract}
In this contribution, we report an overview of the physical attributes of pyroclastic deposit at the foot of Mt. Cameroon, West Africa. In the deposit three facies types; which are the lava flow, the lapilli and ash are common. The ash is the dominant facies and occurs irregularly in alternation with the lapilli. The most common types of depositional features include $\mathrm{cm}-\mathrm{dm}$ planar beds and impact sags. We infer from field observations of facies types, clasts types and depositional features that this deposit is a phreatomagmatic fall deposit which resulted from an interaction between lava flow and surface water. The occurrence in the deposit of accretionary lapilli, impact sags, fragments of country-rock and juvenile clasts is ambiguous evidence in support of phreatomagmatic activity. The presence of a lava flow flanked by the tephra pile, the lack of accidental clasts, and the scarcity of bombs are evidence in support of a surface water-lava flow interaction.
\end{abstract}

KEY WORDS: Pyroclastic Deposit, Batoke, Mt. Cameroon,

\section{INTRODUCTION}

Pyroclastic deposits are a significant volcanic hazard associated with all types of volcanoes (Sigurdsson et al., 1987, Waters and Fisher, 1971, Moore, 1967). Most of these deposits are produced during collapse of eruption columns and some by phreatomagmatic eruptions (Cioni et al., 2003, Formenti et al., 2003, Belousov et al., 2002, Water and Fisher, 1971, Moore, 1967). The importance of understanding the characteristics and dynamics of such deposits is underscored by their deadly nature to numerous populated areas (Johnston et al., 1997, Crandell, 1975). Thus, knowing the composition of pyroclastic deposits in terms of their origin, clasts and facies types can help for future planning in areas of active volcanoes. In this paper we present a volcanological study of pyroclastic deposits at the foot of Mt. Cameroon. The aim is to document field aspects while inferring an origin for this deposit. We hope that this study will find direct implication in hazard planning and management around Mt. Cameroon while contributing to the general study of physical volcanology.

\section{Geological Setting}

The Cameroon Volcanic Line (CVL) is a 1600 $\mathrm{km}$ long chain of Cenozoic volcanoes that extends from the island of Annobon in the Gulf of Guinea into mainland Africa (Fig. 1). The CVL can be divided into three sectors: the oceanic sector made of Annobon, Saõ Tomé and Principe, the continent/ocean boundary composed of Bioko, Etinde and Mt. Cameroon as well as the continental sector made of Mounts Manengouba, Bambouto, Oku, Ngaoundéré Plateau, Mandara Mountains and Biu plateau.

Mt. Cameroon, the only presently active volcano on the CVL is a stratovolcano with an estimated volume and height of about $1200-1250 \mathrm{~km}^{3}$ and $4095 \mathrm{~m}$, respectively (Suh et al., 2003). This mountain rises between two sedimentary basins: the Douala, to the southeast and the Rio del Rey, to the northwest. Its basement, made of Pan-African granites and gneisses, is covered by 3-7 km of Cretaceous to Recent sedimentary rocks from these two basins (Dumort, 1968, Tsafack et al., 2007 and Mathieu et al., 2011). The eruptive style of this volcano has ranged from dominant effusive (Suh et al., 2003) to moderately explosive resulting in the production of pyroclastic deposits and numerous Strombolian cones. There has also been prehistoric phreatomagmatic activity at the volcano (Wandji et al., 2008, Ngwa et al., 2010). With an annual population growth rate of $2.7 \%$ and much infrastructural development at the foot and flanks of this volcano, there is a need for constant monitoring of the edifice to allow for hazard mitigation and management campaigns. This requires the use of many methods amongst which is the physical study of erupted material; the aim of the present work.

\section{Overview of the deposit}

The pyrolcastic deposit exposed at Batoke on the southwest flank of Mount Cameroon was studied. The total surface area covered by this deposit could not be ascertained partly because of human settlements

Caroline N. Ngwa, Institute for Geological and Mining Research, Mt. Cameroon observatory, P.O. Box 370 Buea, South West Region, Cameroon

Linus Nche, Institute for Geological and Mining Research, Mt. Cameroon observatory, P.O. Box 370 Buea, South West Region, Cameroon

Cheo E. Suh, Department of Geology, University of Buea, P.O. Box 63 Buea, South West Region, Cameroon 
and their anthropogenic activities and degradation by the sea. The exposed part of the deposit is about 1650 $\mathrm{m}$ wide. The ejecta common in the tephra deposit include unoxidized black basaltic juvenile clasts, lithic basaltic clasts and ash sized matrix. The lithic basaltic clasts are referred to here as "cognate clast" using the terminalogy of Fisher and Schmincke, (1984). There are no accidental clasts in the deposit. The deposit can be divided into three groups - the lava flow, the lapilli and the ash dominated facies.

\section{Lava flow facies}

At the middle of the pyroclastic deposit, is a lava flow which is $40 \mathrm{~m}$ high and $31 \mathrm{~m}$ wide (Fig. 2). The lava flow is blocky (Fig. 3a) with individual blocks having a maximum length of about $60-70 \mathrm{~cm}$. The surface of these blocks is smooth with little or no mineral grains in hand specimen. The top of the flow is composed of soil, possibly resulting from the weathering of the underlying lava. The tephra deposit flanks this lava flow on both sides. Moving outwards from the flow front, the immediate surrounding pyroclasts are baked and brown in colour (Figs. 2 and 3b). These baked brown areas are composed mostly of particles greater than $2 \mathrm{~mm}$ in diameter (Fig. 3b). In this study, we call such baked rocks 'contact breccias' according to the terminology of Clement (1982). There are no observable depositional structures on these baked brown areas.

\section{Ash-and lapilli-dominated facies}

These are the most common facies at the Batoke pyroclastic deposit. The lapilli-dominated beds mostly occur as clast supported (having about $70 \%$ clasts). These clasts are composed of fragments of cognate as well as juvenile lava. In a few cases, some lapilli-dominated beds are made up mostly of juvenile clasts. In the deposit, there is an alternation of ash-and lapilli-dominated beds (Fig. 4a). This alternation however does not occur in a regular manner and does not define any regular pattern. At distal locations from the flow front, occurs ash-dominated (about 70\% ash) facies. Another important clast type present at Batoke pyroclastic deposit is the accretionary lapilli. The maximum size of these lapilli is $07 \mathrm{~mm}$ in diameter. The accretionary lapilli are commonly found in the lapillidominated beds (Fig. 4b). Structurally, the accretionary lapilli belong to the core type according to Waters and Fisher (1971); Fisher and Schmincke (1984), and the Schumacher and Schmincke (1991) classification schemes.

\section{Depositional structures}

Although the sections are well exposed, there are generally few depositional structures on them. The most common of these structures are centimeter to decimeter planar beds (Fig. 5a). These beds remain planar even as one moves away from the flow front and can be traced laterally. Most of these beds are composed of fine and coarse ash facies. Impact sags (Fig. 5) are observable below either the juvenile bombs or the cognate blocks found mostly in the ash beds. These sags are symmetrical. There are no dune and channel structures in the deposit. All layers are traceable with no evidence of lateral thinning and thickening of individual beds.

\section{Maximum clast size distribution}

According to Palladino and Agosta (1997), maximum clast sizes measured in a given deposit reflect the energetic conditions of the eruption and can also be used to estimate the eruptive parameters (Sottili et al., 2004). Maximum clast sizes from the Batoke pyroclastic deposit were determined based on the method described by Cas and Wright (1987), and Walker (1981), by measuring and averaging the long axes of 3-5 clasts that seemed to be the largest at each bed. Juvenile bombs were scarce while lithic blocks were very scarce to absent in some cases. These juvenile bombs (Fig. 6a) and lithic blocks are non vesicular. There was no evidence of lateral and vertical increase or decrease of these ejecta. The size of an avarage juvenile bomb ranges from 5 to $7 \mathrm{~cm}$ while that of cognate block ranges from $3-8 \mathrm{~cm}$. Accretionary lapilli on their part, measure up to $07 \mathrm{~mm}$. In the classification scheme of Schmid (1981), the pyroclastic deposit falls in the lapillistone to tuff boundary (Fig. 6 b).

\section{Interpretation}

From field observations, the pyroclastic deposit at Batoke is phreatomagamtic in origin. Unlike pheatomagmatic deposits which are formed as a result of rising magma- ground water interaction (e.g., Ngwa et al., 2010, Befus et al., 2008), the Batoke pyroclastic deposit resulted from magma-surface water interaction. The presence of the lava flow flanked by the pyroclastic deposit (Fig. 2), scarcity of lithic and juvenile bombs, as well as the absence of accidental fragments from the deposit enable us to suggest that the phreatomagmatic activity did not involve ascending magma and ground water. Instead, there was an interaction of this lava flow when it was in motion with surface water which then resulted in the fragmentation of the advancing lava. The small sizes of the bombs $(5$ to $7 \mathrm{~cm})$ also support this interpretation.

We interpret the presence of accretionary lapilli, impact sags and the widespread occurrence of planar beds to indicate the presence of moisture during formation, transportation or deposition (Crowe and Fisher, 1973, Lorenz, 1974, 1985, Nemeth et al., 2001).

Grain-size distribution of tephra-fall deposits is a crucial eruptive parameter necessary for hazard mitigation plans as it is used in tephra-dispersal modeling to assess the risk and vulnerability of populations (e.g Barberi et al., 1990; Connor et al., 2001; Bonadonna et al., 2002). It is also an important indication of the level of particulate pollution dangerous for human health (e.g. Moore et al., 2002). The dominance of ash and lapilli facies over bombs in this Batoke tephra deposit, calls for more awareness of the population at the foot and flanks of Mt. Cameroon as a whole as ash particles during eruptions are dangerous to humans, plants and animals. Ash produced by volcanic eruptions can lead to the closure of airports, state highway as well a caused damage to hydroelectric power facilities, (Johnston et al., 2000, Guffanti et al., 2003). 


\section{DISCUSSION}

The data presented in this paper throw light on the physical volcanology of the pyroclastic deposit at Batoke, Mt. Cameroon. Observed charateristics of this deposit such as: juvenile and lithic particles, lack of vesicularity of the juvenile clasts are typical of

phreatomagamtic tephra (White and Houghton, 2000, Lorenx, 1985, Zimanowski, 1998). Although there are indications of moisture (impact sags, accretionary lapilli) during formation of the tephra deposit, we infer from the absence of dunes, channel structures, the symmetrical nature of impact sags, lack of lateral thinning and thickening of individual beds, as well as no interfingering of beds that although water was involved during fragmentation, the water was not enough to be involved in the transportation. Pyroclastic deposits transported by surface water will have channel structures, dunes and in most cases asymmetrical impact sags, usable in tracing the direction of flow. Thus, we conclude that due to the lack of the above mentioned depositional features, the presence of impact sags under bombs is rather an indication of deformation during fall. Studies elsewhere (e.g., Befus et al., 2008) have shown that the presence of impact sags in phreatomagmatic deposit is typical evidence of direct fallout from eruption columns during pulsatory phreatomagmatic eruptions. Impact sags are also indicative of the plastic deformation of beds underneath the blocks (Lorenz, 1985) as well as the energy of ejection.

A phreatomamagtic deposit resulting from magma - ground water interaction would have an intermixture of cognate, juvenile and accidental ejecta types. Such a deposit is an indication of significant quarrying of the vent zone (Nemeth, 2003) as a result of high-energy phreatomagmatic explosion (Zimanowski, 1998). These deposits will indicate a complex fragmentation regime (White and Schmincke, 1999) and the population of the different ejecta types will also decrease laterally away from the crater and vertically up the deposit (e.g Ngwa et al., 2010). However, these variations are not observed at the Batoke pyrolcastic deposit. Phreatomagmatic activity at Batoke was possibly initiated by a simple lava flow-surface water interaction during which there was no 'throat clearing' activity which would lead to a mixture of different eject types. More so, one will expect to have particles of sedimentary rocks typically shale and sandstone in the deposit (Ngwa et al., 2010) because the basement of Mt. Cameroon is covered by $3-7 \mathrm{~km}$ of Cretaceous to Recent sedimentary rocks from Douala and Rio del Rey basins between which the mountain rises (Dumort, 1968, Tsafack et al., 2007 and Mathieu et al., 2011).

\section{CONCLUSION}

The Batoke pyroclastic deposit is a phreatomagmatic fall deposit which resulted from the interaction between an advancing lava flow and surface water. The deposit consists of alternations of ashdominated and lapilli-dominated facies. The conspicuous depositional feature present is the $\mathrm{cm}-\mathrm{dm}$ planar ash bedding. These beds alternate with lapilli dominated beds although not in a regular manner. Impact sags indicate deformation during fall while accretionary lapilli indicate wetness during formation of pyroclastic material. The lack of flow depositional structures within the deposit is indicative of the absence of water during transportation.

\section{ACKNOWLEDGEMENTS}

This work was carried out under the Mt. Cameroon monitoring project of the Volcano Observatory at Ekona Buea. We are grateful for the assistance received from Richard Teghem, a driver at the Mt. Cameroon Observatory (ARGV) Ekona and the administrative authorities at Batoke during field work. 


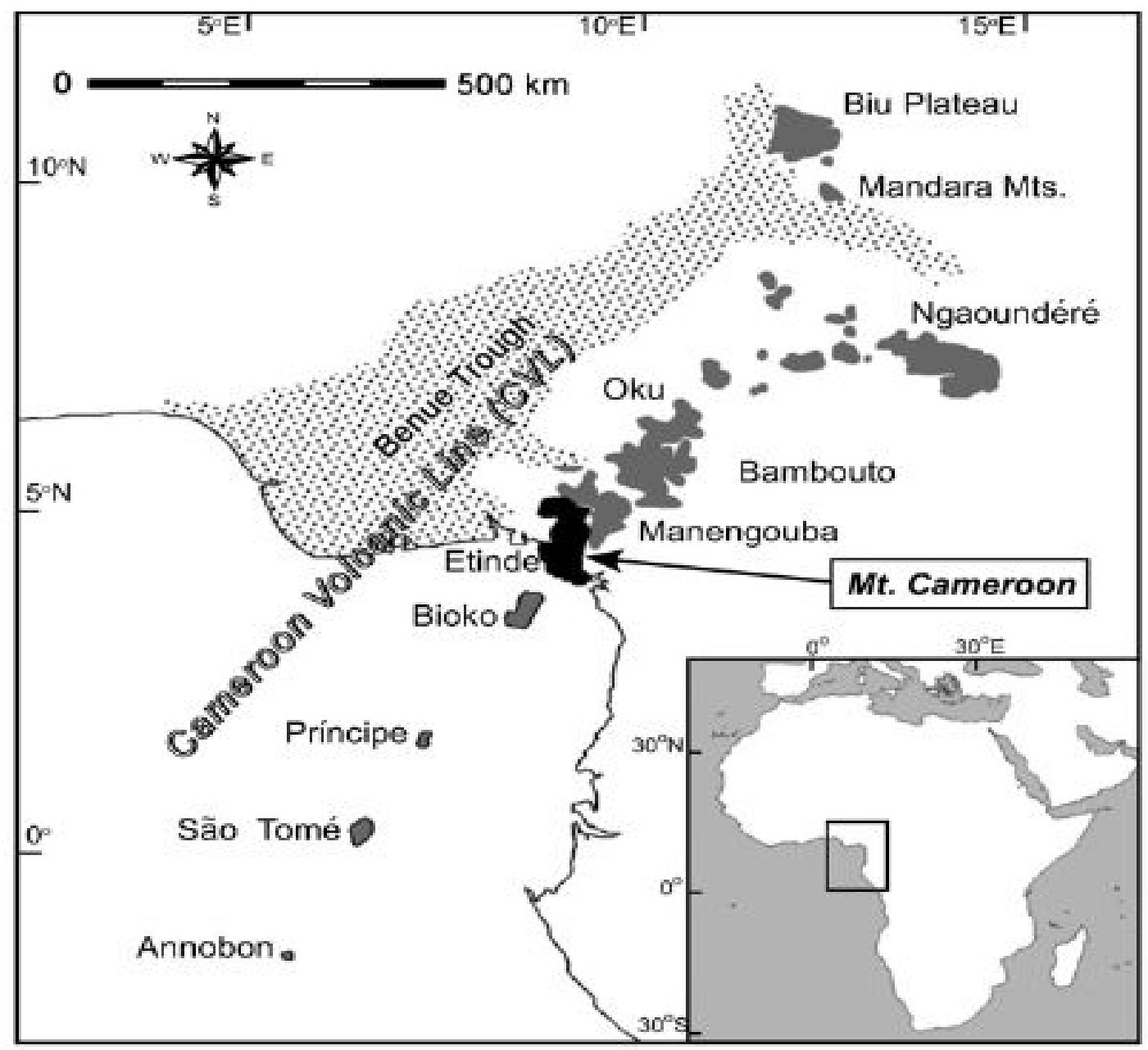

Figure 1: Map of the Cameroon volcanic line showing the main volcanic centers indicated in black: Map taken from Yokoyama et al., 2007 


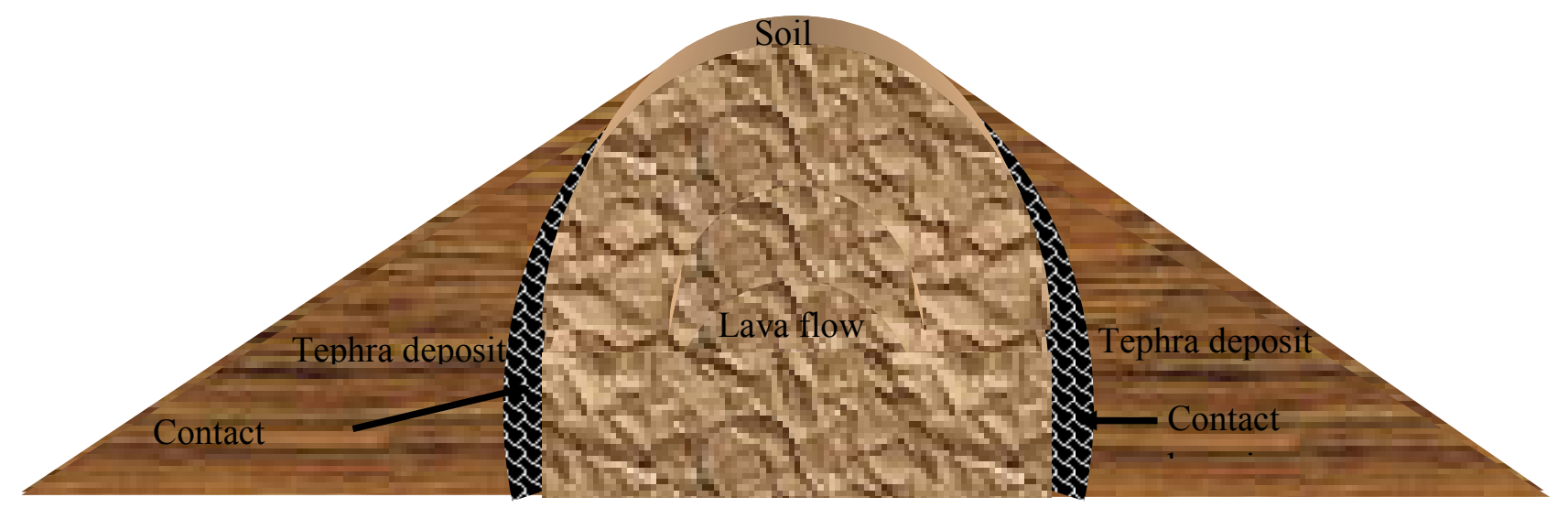

Figure 2: Cross-section representation of the general view of the pyroclastic deposit (Diagram is not drawn to scale)
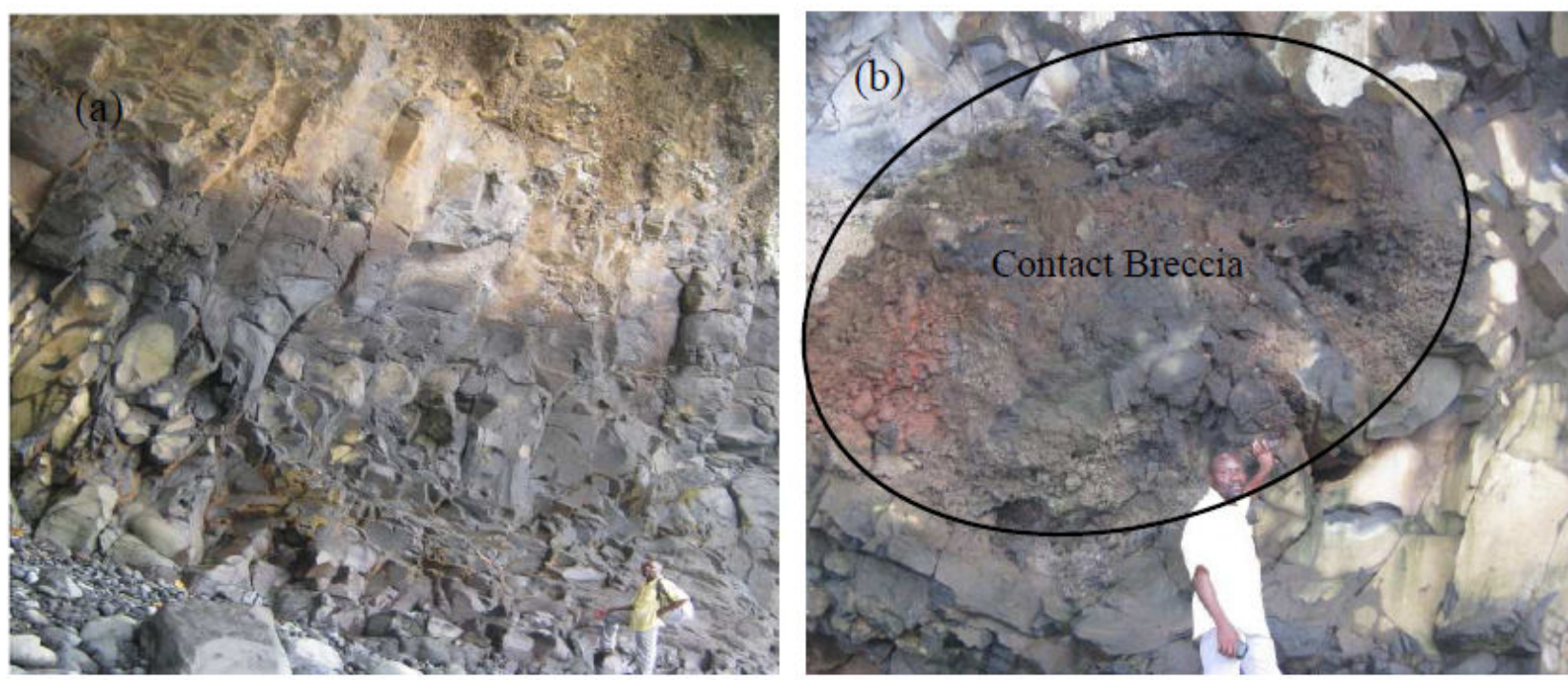

Figure 3: Photographs of (a) Blocky Lava flow at Batoke and (b) contact breccia found at the pyroclastic deposit 

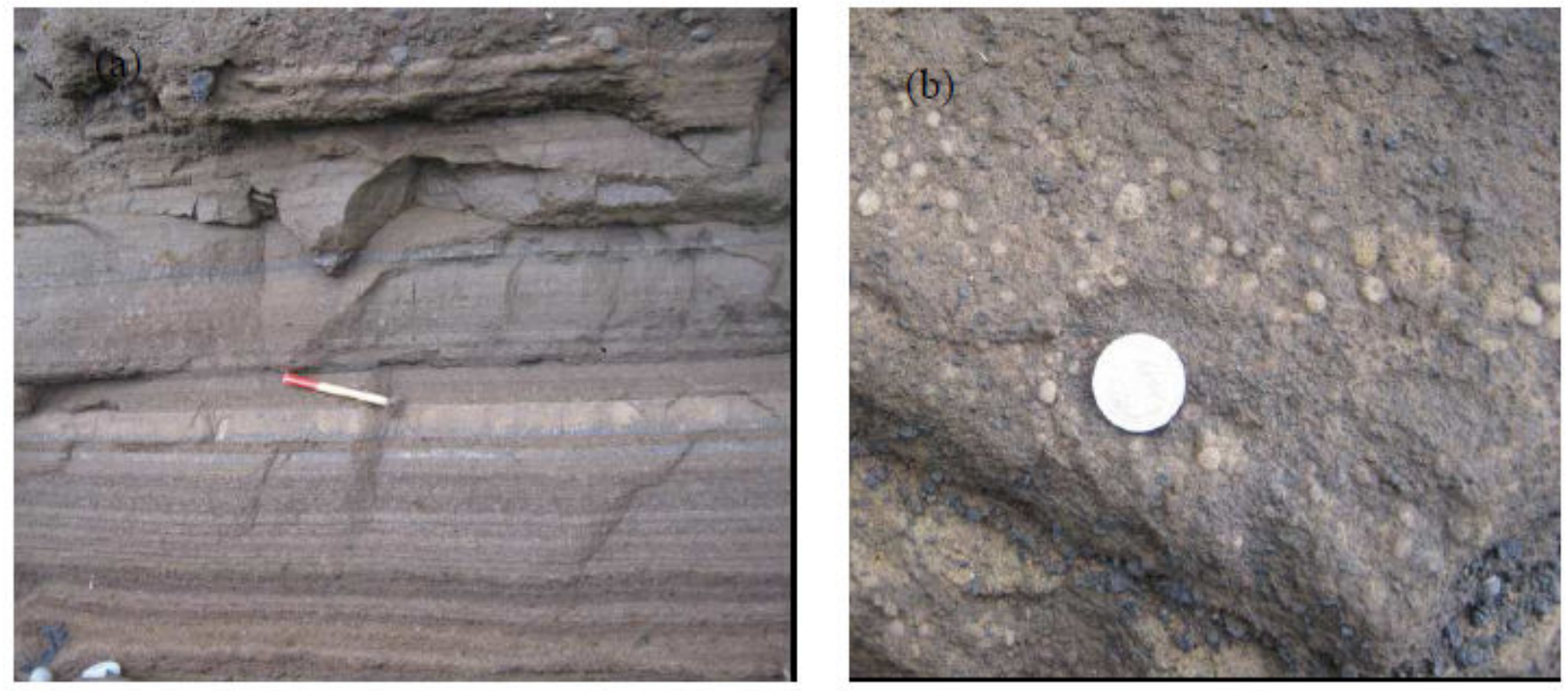

Figure 4: View of ash and lapilli dominated beds. Note the coarse lapilli beds at the top of the section. (b) Accretionary lapilli within Batoke tephra deposit. Coin is $2.1 \mathrm{~cm}$ in diameter.
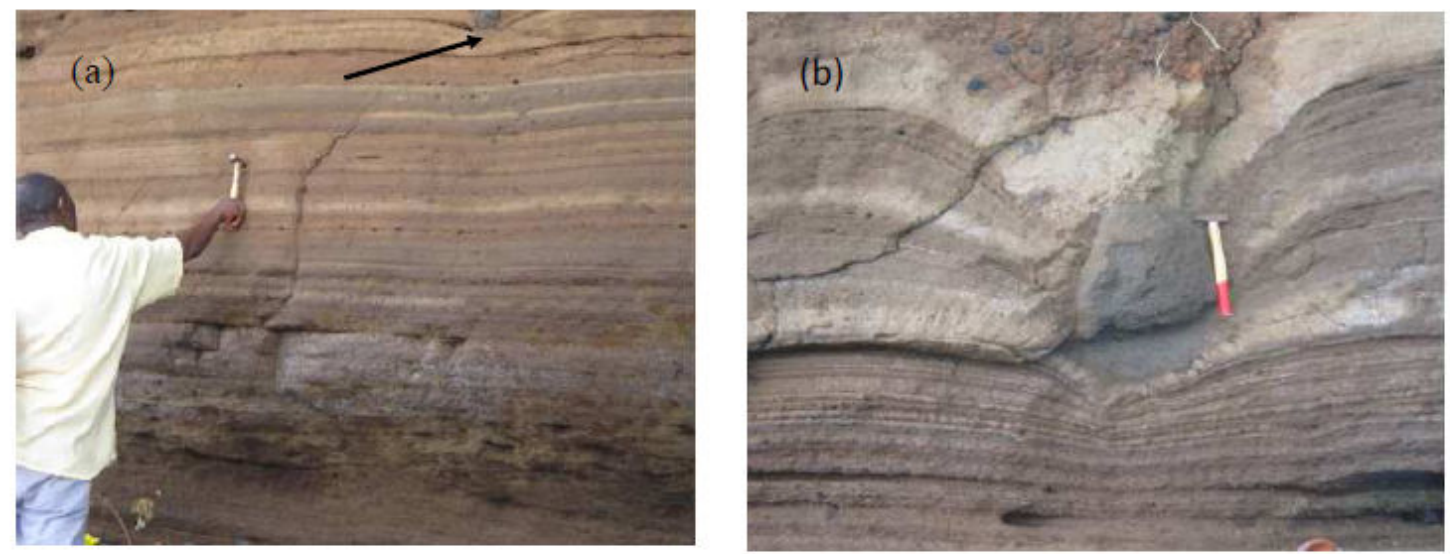

Figure 5: (a) View of dc-cm planar beds at the Batoke pyrolcastic deposit. Note the small impact sag at the top of section (b) Symmetical sag beneath a bomb. 

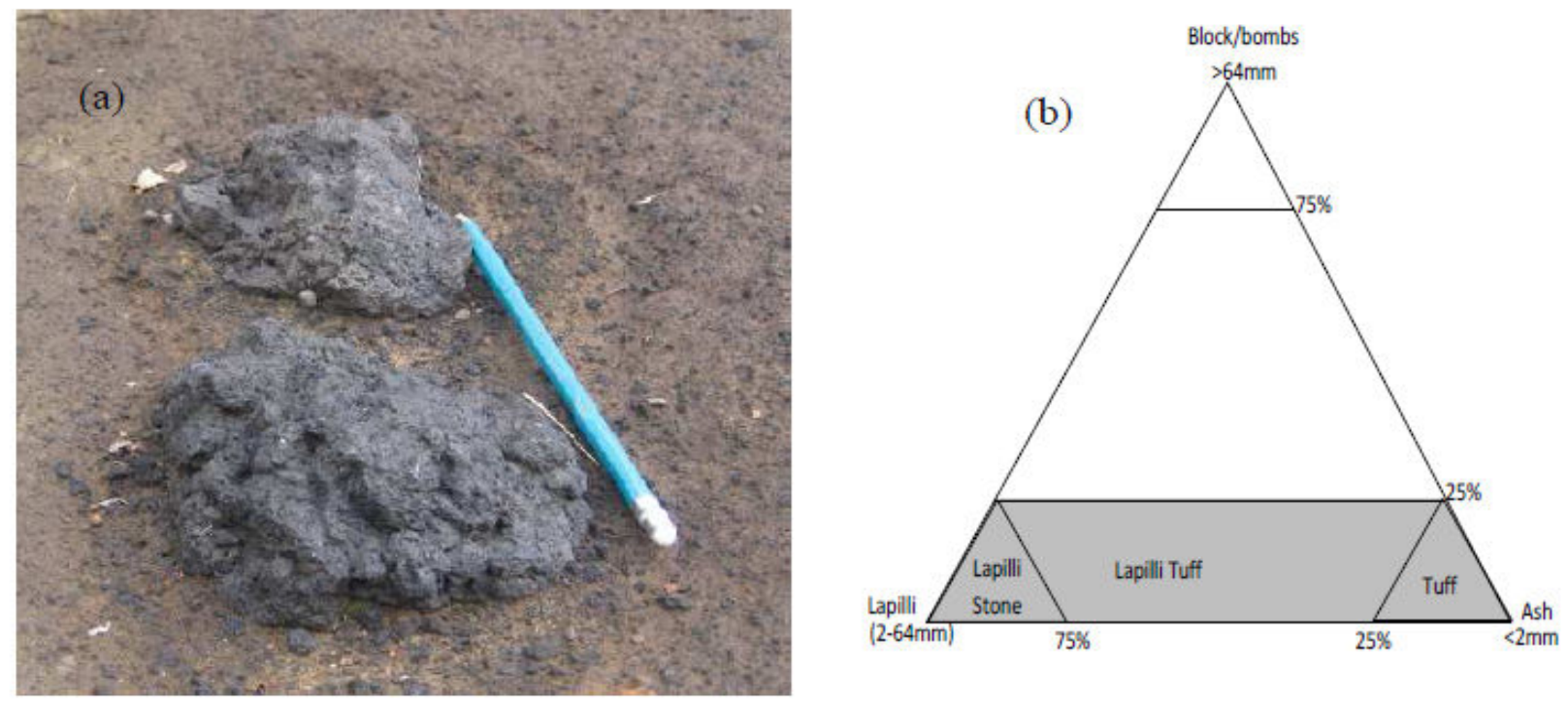

Figure 6: (a) Two juvenile bombs at the deposit. Pencil is $18.8 \mathrm{~cm}$ long, (b) Schematic classification of the Batoke tephra deposit. Deposit generally falls in the lapillistone to Tuff section of Schmid (1981) classification scheme

\section{REFERENCES}

Barberi F, Macedonio, G., Pareschi, M. T, and Santacroce, R., 1990. Mapping the tephra fallout risk: an example from Vesuvius, Italy. Nature 344, $142-144$

Befus, K. S., Hanson, R. E., Lehman, T. M., and Griffin, W. R., 2008. Cretaceous basaltic phreatomagmatic volcanism in west Texas: maar complex at Pena Mountain, Big Bend National park. Journal of Volcanology and Geothermal Research 173, 245-264.

Belousov, A., Voight, B., Belousova, M., and Petukhin, A., 2002. Pyroclastic surges and flows from the 8-10 May 1997 explosive eruption of Bezymianny volcano, Kamchatka, Russia. Bulletin of Volcanology 64, 455-471.

Bonadonna, C., Macedonio, G., Sparks, R. S. J., 2002. Numerical modelling of tephra fallout associated with dome collapses and Vulcanian explosions: application to hazard assessment on Montserrat. In: Druitt TH, Kokelaar BP (eds) The eruption of Soufri\$re Hills Volcano, Montserrat, from 1995 to 1999. Memoir, Geological Society, London, pp 517-537

Cas, R. A. F., Wright, J. V., 1987. Volcanic Successions: Modern and Ancient. Allen \& Unwin, London. $528 \mathrm{pp}$.
Cioni, R., Sulpizo, R., Garruccio, N., 2003. Variability of eruption dynamics during a Subplinian event:the Greenish Pumice eruption of SommaVesuvius (Italy). Journal of Volcanology and Geothermal Research 124, 89-114

Clement, C. R., 1982. A comparative geological study of some major kimberlite pipes in the Northern Cape and Orange Free State: Unpublished Ph. D. thesis, Cape Town, University of Cape Town, South Africa, 2 volumes. IXX+432 p. + $406 p$

Connor, C. B., Hill, B. E., Winfrey, B., Franklin, N. M., La

Femina, P. C., 2001. Estimation of volcanic hazards from tephra fallout.Natural Hazards Review $2: 33-42$

Crandell, D. R., 1975. Assesssment of volcanic risk on island of Oahu, Hawaii, U.S Geological Survey Open-File 75-287.

Crowe, B. M., Fisher, R. U., 1973. Sedimentary structures in base surge deposit with special reference to cross bedding, Ubehebe Craters, Death Valley, California. Geological Society of America Bulletin 84, 663-682.

Dumort, J. C., 1968. Notice Explicative de la Feuille Douala Ouest avec carte gélogique au 1/500 000. Direction des Mines, Géologie, Cameroon, scale 1:500,000 
Fisher, R. V., and Schmincke, H. U., 1984. Pyroclastic rocks. Springer-verlag, Berlin. $472 \mathrm{pp}$.

Formenti, Y., Druitt, T. H., Kelfoun, K., 2003. Characterisation of the 1997 Vulcanian explosions of Soufriere HillsVolcano, Montserrat, by video analysis. Bulletin of Volcanology 65, 587-605

Guffanti, M., Gari C. Mayberry., Thomas P. Miller., 2003. Impact of Volcanic Activity on Airports: Presented at 3rd International Workshop on Volcanic Ash, Toulouse, 29 Sept-3 Oct 2003

Johnston, D. M., Nairn, I. A., Thordarson, T., Daly, M.

1997. Volcanic impact assessment for Auckland volcanic field. Auckland Regional Council Technical 79.

Johnston, D., and Ronan, K., 2000. Risk education and intervention. In: H. Siggurdson (Ed.), Encyclopedia of Volcanoes. Academic Press, New York, 1229-1240.

Lorenz, V., 1974. Vesiculated tuffs and associated features. Sedimentology 21, 273-291.

Lorenz, V., 1985. Maars and diatremes of phreatomagmatic origin, a review. Transactions of the Geological Society of South Africa 88, 459-470.

Mathieu, L., Kervyn, M., and Ernst G. G. J., 2011. Field evidence for flank instability, basal spreading and volcano-tectonic interactions at Mt.Cameroon, West Africa. Bulletin of Volcanology, DOI 10.1007/s00445-011-0458-z

Moore, J. G., 1967. Base surge in recent volcanic eruptions. Bulletin of Volcanology. 30, 337-363.

Moore K., R, Duffell, H., Nicholl, A, Searl A., 2002. Monitoring of airborne particulate matter during the eruption of Soufrière Hills Volcano, Montserrat. In: Druitt TH, Kokelaar BP (eds)

The eruption of Soufriè re Hills Volcano, Montserrat, from 1995 to 1999. Memoir, Geological Society, London, pp 557-566

Nemeth, K., Martin, U., and Harangi, S. Z., 2001. Miocene phreatomagmatic volcanismat Tihany (Pannonian Basin, Hungary). Journal of Volcanology and Geothermal Reseacrh 111, 111-135.

Nemeth, K., 2003. Calculation of long-term erosion in Central Otago, New Zealand, based on erosional remants of maar/tuff rings. Zeitschrift für Geomorphologie supplementband 47, 29-49

Nkoumbou, C, Déruelle B, Velde D., 1995. Petrology of Mt Etinde nephlinite series. Journal of Petrololgy 36, 373-395
Ngwa, C. N, Suh, C. E. Devey, C. W., 2010. Phreatomagmatic deposits and stratigraphic reconstruction at Debunscha Maar. (Mt Cameroon volcano) Journal of Volcanology and Geothermal Research 192, 201-211

Palladino, D., and Agosta, E., 1997. Pumice fall deposits of western Vulsini Volcanoes (central Italy). Journal of Volcanology and Geothermal Research 78, 77-102

Schmid, R., 1981. Descriptive nomenclature and classification of pyroclastic deposits and fragments: recommendation of the IUGS subcommission on the Systematics of Igneous Rocks. Geology 9, 41-43.

Schumacher, R.,and Schmincke, H. U., 1991. Internal structure and occurrence of accretionary lapilli a case study at Laacher See Volcano. Bulletin of Volcanology 53, 612-634

Sottili, G., Palladino, D.M., Zanon, V., 2004. Plinian activity during the early eruptive history of the Sabatini Volcanic District, central Italy. Journal of Volcanology and Geothermal Research 135.361-379

Sigurdsson, H., Devine, F.M., Tchoua, T.S., Pringle, M.K.W., Evans, W.C., 1987. Origin of the Lethal gas bust from Lake Monoun, Cameroon. Journal of Geothermal Research 31, 1-16

Suh, C. E., Sparks, R. S. J., Fitton, J. G., Ayonghe, S. N., Annen, C., Nana, R. and Luckman, A., 2003. The 1999 and 2000 eruptions of Mount Cameroon: eruption behaviour and petrochemistry of lava. Bulletin of Volcanology, 65: 267-281.

Tsafack, J. P. F, Wandji, P, Bardintzeff, J. M, Nkouathio D. G., 2007. Occurrence of a sedimentary basement under the Mount Cameroon active volcano (Cameroon Volcanic Line). $26^{\text {th }}$ ECGS (European Center for Geodynamics and Seismology) Worshop, Active Volcanism and Continental Rifting (AVCOR-07), Luxembourg, November 19-21, 2007

Walker, G. P. L., 1981. Characteristics of two phreatoplinian ashes, and their water-flushed origin. Journal of Volcanololgy Geothermal Research 9, 395-407

Waters, A. C., Fisher, R. V., 1971. Base surges and their deposits: Capelinhos and Taal volcanoes. Journal of Geophysical Research 76, 5596-5614

Wandji, P., Tsafack, J. P. F., Bardintzeff, J. M., Nkouathio, D. G., Kagou Dongmo, A., Bellon, H., Guillou, H., 2008. Xenoliths of dunites wehrlites and clinopyroxenites in the basanites from Batoke volcanic cone (Mount Cameroon, Central Africa): petrogenetic implications. Mineralogy and Petrology. doi:10.1007/s00710-008-0040-3. 
White, J. D. L., and Schmincke, H.-U., 1999. Phreatomagmatic eruptive and depositional processes during the 1949 eruption on La Palma (Canary Islands). Journal of Volcanology and Geothermal Research 94, 283-304.

White, J. D. L., and Houghton, B., 2000. Surtseyan and related phreatomagmatic eruptions. In: Sigurdsson, H., Houghton, B.F., et al. (Eds.), Encyclopedia of Volcanoes. Academic Press, 495-511.
Yokoyama T., Aka F. T., Kusakabe, M., Nakamura, E., 2007. Plume-lithosphere interaction beneath Mt. Cameroon volcano, West Africa: Constraints from 238U-230Th-226Ra and $\mathrm{Sr}-\mathrm{Nd}-\mathrm{Pb}$ isotope systematics. Geochimica et Cosmochimica Acta 71, 1835-1854

Zimanowski, B., 1998. Phreatomagmatic explosions. In: Freundt, A., Rosi, M. (Eds.), From Magma to Tephra. Elsevier, Amsterdam, 25-53. 